\title{
Inhibition of insulin secretion, but normal peripheral insulin sensitivity, in a patient with a malignant endocrine pancreatic tumour producing high amounts of an islet amyloid polypeptide-like molecule
}

\author{
M.Stridsberg ${ }^{1}$, C.Berne ${ }^{2}$, S. Sandler ${ }^{3}$, E. Wilander ${ }^{4}$, K. Öberg $^{5}$ \\ ${ }^{1}$ Department of Clinical Chemistry, University Hospital, Uppsala, Sweden \\ ${ }^{2}$ Departments of Internal Medicine and Geriatrics, University Hospital, Uppsala, Sweden \\ ${ }^{3}$ Department of Medical Cell Biology, Uppsala University, Uppsala, Sweden \\ ${ }^{4}$ Department of Pathology, University Hospital, Uppsala, Sweden \\ ${ }^{5}$ Department of Internal Medicine and Ludwig Institute for Cancer Research, University Hospital, Uppsala, Sweden
}

\begin{abstract}
Summary. Islet amyloid polypeptide or amylin is a polypeptide secreted mainly from the pancreatic beta cells together with insulin upon stimulation. High levels of islet amyloid polypeptide have also been shown to increase the peripheral insulin resistance and consequently a role for islet amyloid polypeptide in the glucose homeostasis has been suggested. We have studied the glucose homeostasis in a patient with a malignant endocrine pancreatic tumour producing large amounts of an islet amyloid polypeptide-like molecule (about 400 times the upper reference level for islet amyloid polypeptide). This patient developed insulin-requiring diabetes mellitus shortly after the tumour diagnosis. Both intravenous and oral glucose tolerance tests revealed inhibited early responses in insulin and C-peptide release, but the insulin and C-peptide response to glucagon stimulation was less affected. Aneuglycaemic insulin clamp showed normal insulin-mediated glucose disposal. In vitro experiments, where isolated rat pancreatic islets were cultured with serum
\end{abstract}

from the patient, showed a moderately decreased islet glucose oxidation rate and glucose-stimulated insulin release compared to islets cultured with serum from healthy subjects. However, culture of rat islets with normal human serum supplemented with synthetic rat islet amyloid polypeptide did not affect the glucose-stimulated insulin release. In conclusion, the observed effects show that the diabetic state in this patient was associated with an impaired glucose-stimulated insulin release but not with an increased peripheral insulin resistance. Thus, the results suggest that if islet amyloid polypeptide has diabetogenic effects they are more likely to be exerted at the level of insulin secretion than at the level of peripheral insulin sensitivity.

Key words: Amylin, endocrine pancreatic tumour, glucose tolerance, insulin resistance, islet amyloid polypeptide, pancreatic islets.
Islet amyloid polypeptide (IAPP) or amylin was first purified and sequenced from an endocrine pancreatic tumour producing insulin $[1,2]$ and later from pancreas of patients with Type 2 (non-insulin-dependent) diabetes mellitus [3]. IAPP obtained from these sources was found to be a 37 amino acid polypeptide with about $50 \%$ amino acid homology with calcitonin gene related peptide (CGRP). Studies with immunocytochemical $[4,5]$, radioimmunoassay [6] and Northern blot techniques [7] have indicated that the main production site of IAPP are the pancreatic beta cells, although small amounts of IAPP have also been found in the upper gastrointestinal tract and in the lung. By electronmicroscopical immunocytochemistry it was observed that IAPP co-exists with insulin within the betacell granules [8] and IAPP is also co-released with insulin upon stimulation of secretion $[9,10]$.

Because of its close topographic relation to insulin a role for IAPP in the glucose homeostasis has been suggested [11]. Studies of the effects of IAPP upon glucose- stimulated insulin secretion are contradictory. Some studies have shown inhibition of stimulated insulin secretion in the presence of IAPP [12-17], while others have been unable to record any effects [18-21]. The described peripheral effects of IAPP include a dose-dependent decrease of insulin-stimulated glucose uptake and glycogen synthesis in skeletal muscle and in liver $[22,23]$. IAPP has also been reported to bind to CGRP receptors in liver cells [24]. Furthermore, IAPP has been shown to exert hypocalcaemic and vasodilator effects $[25,26]$.

We recently identified a patient with a malignant endocrine pancreatic tumour, with multiple liver metastases, that produces large amounts of an IAPP-like molecule [27]. This patient subsequently developed manifest insulin-requiring diabetes during tumour progression.

The aim of the present study was to perform a metabolic characterization of the diabetes in this patient and to investigate the relationship between the high circulating 

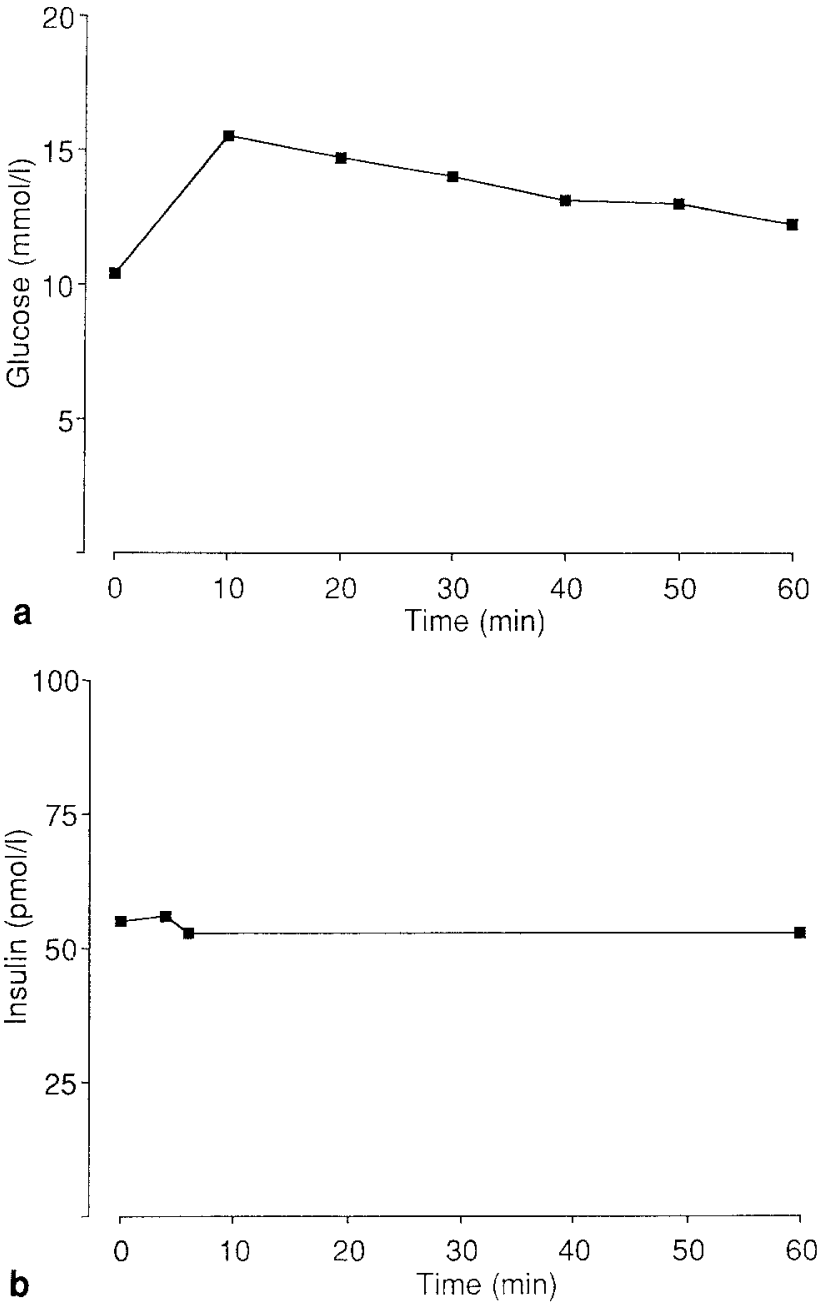

Fig.1a-d. Concentrations of blood glucose, serum insulin, serum Cpeptide and plasma islet amyloid polypeptide (IAPP) during an intravenous glucose tolerance test $(0.35 \mathrm{~g}$ glucose $/ \mathrm{kg}$ body weight)

levels of the IAPP-like molecule and the regulation of the insulin secretion as well as the insulin-mediated glucose disposal rate.

\section{Subjects, materials and methods}

\section{The patient}

The patient was a 50-year-old man with a malignant endocrine pancreatic tumour with multiple liver metastases, who was admitted to the endocrine ward of Uppsala University hospital for diagnosis and anti-tumour treatment. The malignant disease of this patient has been described in detail previously [27]. Diabetes has not been reported amongst the first degree relatives of the patient. Shortly after the tumour diagnosis he was found to have immensely increased blood levels of IAPP immunoreactive material at about 400 times the reference range for normal subjects. This immunoreactive material was probably a pro-peptide with a molecular weight of $6300 \mathrm{Da}$. A study is in progress to further characterise the peptide produced from this patient. Preliminary data indicate that the pep-
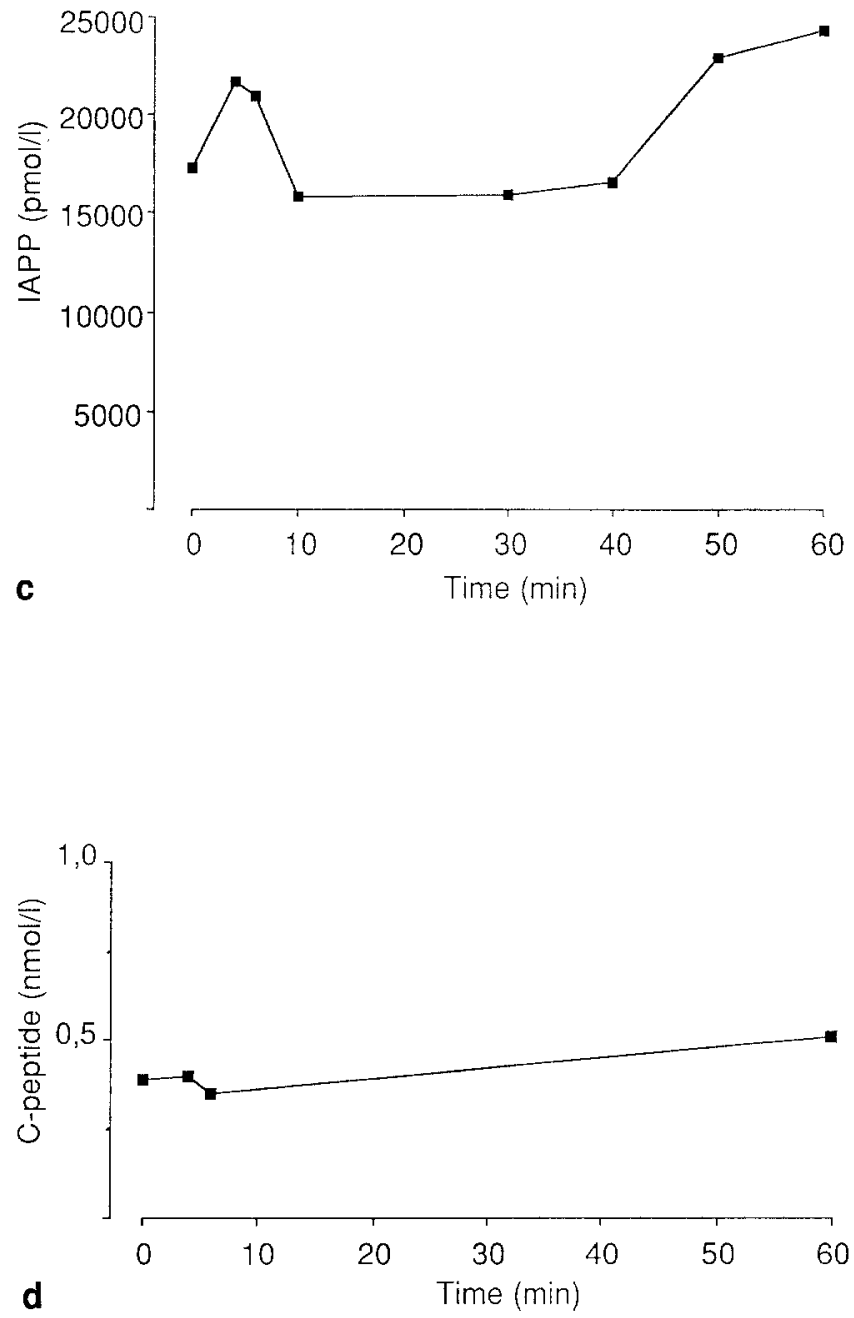

tide is normally processed in the $\mathrm{N}$-terminal but has an elongation of 6 amino acids in the C-terminal (unpublished result). At the time of tumour diagnosis the blood glucose levels varied between 5.4 and $6.4 \mathrm{mmol} / \mathrm{l}$ during the day. Within 1 year the patient became diabetic with fasting blood glucose levels of $20-40 \mathrm{mmol} / \mathrm{l}$ and insulin treatment was started. The insulin requirements were about $50 \mathrm{IU} / \mathrm{day}$, divided into four daily doses of human insulin. One month later an oral glucose tolerance test was performed. The fasting blood glucose levels during the test increased from about 8 to $16 \mathrm{mmol} / 1$ while the insulin remained at basal levels of about 40 pmol/l (cf. fig. 6 in [27]). About 6 months later an intravenous glucose tolerance test was performed. Again blood glucose increased from about 8 to $16 \mathrm{mmol} / \mathrm{l}$ during the test with no effects on the insulin levels (unpublished data). Two years after the tumour diagnosis the patient showed signs of tumour progression and streptozotocin treatment was started. During a 1.5-year period the patient received a total of $58 \mathrm{~g}$ of streptozotocin. The patient responded to the streptozotocin treatment and thus, was able to resume a fairly normal life, working part time. Unexpectedly, the patient suffered a cerebral haemorrhage and died within $12 \mathrm{~h}$ in his local hospital. Except for the confirmation of the haemorrhage no autopsy was performed.

\section{Metabolic investigations}

After an overnight fast the patient was, on separate days, exposed to an intravenous glucose tolerance test $(0.35 \mathrm{~g} / \mathrm{kg}$ body weight $)$, a 75-g oral glucose tolerance test and an euglycaemic insulin clamp 
[28]. The target plasma glucose level during the clamp was maintained at $5.3 \mathrm{mmol} / 1$ by plasma glucose measurements with 5 -min intervals and adjustment of the infusion rate of $20 \%$ glucose solution. The infusion rate of insulin was $56 \mathrm{mU} / \mathrm{m}^{2} \cdot \mathrm{min}$. Glucose disposal was calculated from the amount of glucose infused and metabolized per unit of plasma insulin during the steady-state levels of the last $50 \mathrm{~min}$ of the clamp [29]. Blood samples for measurements of IAPP, insulin and C-peptide were collected at regular intervals during the tests. The hormone responses to an intravenous injection of $0.5 \mathrm{mg}$ glucagon were also studied. Further, samples were collected after an overnight fast for determination of $\mathrm{HbA}_{1 \mathrm{c}}$, serum lipids and islet cell antibodies [30]. Plasma IAPP was measured by a recently established radioimmunoassay [27]. The assay, which uses standard IAPP and a polyclonal rabbit antiserum (Peninsula Laboratories, Belmont, Calif., USA), is a method for direct measurements of IAPP in plasma. The sensitivity was $0.125 \mathrm{fmol} /$ tube $(1.25 \mathrm{pmol} / \mathrm{l}$ plasma) and the reference interval for normal subjects was calculated to less than $60 \mathrm{pmol} / \mathrm{l}$. Serum insulin and C-peptide were measured by commercial radioimmunoassay kits (PharmaciaLKB, Uppsala, Sweden). Other agents were analysed by conventional routine methods.

\section{Islet experiments}

The response of isolated rat pancreatic islets to the patient's serum was examined in vitro. Pancreatic islets from male adult SpragueDawley rats were isolated and precultured free-floating for 6 days in medium RPMI $1640+10 \%$ fetal calf serum (Flow Laboratories, Irvine, UK) at $37^{\circ} \mathrm{C}$ in air $+5 \% \mathrm{CO}_{2}$. The islets were then transferred in groups of 85 to new culture dishes containing the same culture medium, but supplemented to $10 \%$ with either pooled normal human serum or serum from the patient. The medium was changed after 2 days. After 4 days islet glucose oxidation rates at $16.7 \mathrm{mmol} / \mathrm{l}$ glucose and insulin release at $1.7 \mathrm{mmol} / \mathrm{l}$ and $16.7 \mathrm{mmol} / 1$ glucose concentrations were examined in short-term experiments [31]. The accumulated insulin concentrations in the culture medium were measured after 2 and 4 days as well as the insulin and DNA contents of the islets. In a separate series of experiments rat islets were cultured with $10 \%$ pooled normal human serum supplemented with either 0,2 or $200 \mathrm{nmol} / \mathrm{l}$ of synthesized rat IAPP (Peninsula Laboratories) respectively. The $2 \mathrm{nmol} / 1$ concentration corresponds to the circulating plasma levels of measured IAPP in the patient after a 10-fold dilution. After 4 days, insulin release experiments were performed as described above.

\section{Statistical analysis}

Where applicable values are computed as mean \pm SEM and compared using Student's paired $t$-test.

\section{Results}

The patient was in satisfactory metabolic control with an $\mathrm{HbA}_{\mathrm{lc}}$ of $6.7 \%$ (reference range 3.5-6.0\%) and fasting blood glucose levels at about $8 \mathrm{mmol} / \mathrm{l}$. Serum cholesterol was $6.5 \mathrm{mmol} / \mathrm{l}$ (reference range $2.7-7.1 \mathrm{mmol} / \mathrm{l}$ ), serum triglycerides $2.5 \mathrm{mmol} / \mathrm{l}$ (reference range $0.23-$ $1.70 \mathrm{mmol} / \mathrm{l}$ ) and HDL cholesterol $1.12 \mathrm{mmol} / \mathrm{l}$ (reference range $1.0-2.5 \mathrm{mmol} / \mathrm{l})$. No islet cell antibodies were detected. The measured plasma IAPP concentrations were high, oscillating between 15000 and $25000 \mathrm{pmol} / \mathrm{l}$, which is about 400 times the upper reference level of IAPP $(<60 \mathrm{pmol} / \mathrm{l})$ for healthy subjects.
Table 1. Effects of adding serum from the patient with an endocrine pancreatic tumour secreting an islet amyloid polypeptide-like molecule (IAPP) and normal human serum (NHS) on function of rat pancreatic islets in culture

\begin{tabular}{lll}
\hline & IAPP & NHS \\
\hline $\begin{array}{l}\text { Glucose oxidation rate } \\
\text { (pmol glucose } / 10 \text { islets } \times 90 \mathrm{~min} \text { ) }\end{array}$ & $228 \pm 27^{\mathrm{b}}$ & $327 \pm 42$ \\
$\begin{array}{l}\text { Medium insulin accumulation day } 2 \\
\text { (ng insulin/ } 85 \text { islets } \times 48 \mathrm{~h} \text { ) }\end{array}$ & $7080 \pm 1870$ & $6930 \pm 1920$ \\
$\begin{array}{l}\text { Medium insulin accumulation day } 4 \\
\text { (ng insulin } / 85 \text { islets } \times 48 \mathrm{~h} \text { ) }\end{array}$ & $6300 \pm 1110$ & $6900 \pm 1300$ \\
$\begin{array}{l}\text { Insulin release at } 1.7 \mathrm{mmol} / \mathrm{l} \text { glucose } \\
\text { (ng insulin/10 islets } \times 60 \mathrm{~min} \text { ) }\end{array}$ & $11.5 \pm 1.1$ & $9.8 \pm 1.1$ \\
$\begin{array}{l}\text { Insulin release at } 16.7 \mathrm{mmol} / \mathrm{l} \text { glucose } \\
\text { (ng insulin } / 10 \text { islets } \times 60 \mathrm{~min} \text { ) }\end{array}$ & $62.7 \pm 9.5^{\mathrm{a}}$ & $86.4 \pm 10.3$ \\
$\begin{array}{l}\text { Insulin content } \\
\text { (ng insulin/10 islets) }\end{array}$ & $470 \pm 25$ & $576 \pm 44$ \\
$\begin{array}{l}\text { DNA content } \\
\text { (ng DNA } 10 \text { islets) }\end{array}$ & $310 \pm 40$ & $330 \pm 50$ \\
\hline
\end{tabular}

Rat pancreatic islets were pre-cultured for 6 days in medium RPMI $1640+10 \%$ fetal calf serum at $37^{\circ} \mathrm{C}$ in air $+5 \% \mathrm{CO}_{2}$. Then islets in groups of 85 were transferred to new culture dishes containing the same culture medium, but supplemented with either $10 \%$ pooled NHS or $10 \%$ IAPP serum. The medium was changed after 2 days. After 4 days the islets were subsequently examined in glucose oxidation (16.7 mmol/1) and insulin release (1.7 and $16.7 \mathrm{mmol} / 1)$ experiments. Values are means \pm SEM for 11 experiments (glucose oxidation and medium insulin accumulation) and 8 experiments (insulin release, insulin and DNA content). ${ }^{a} p<0.05,{ }^{\mathrm{b}} p<0.01$ vs NHS, using Student's paired $t$-test

During the intravenous glucose tolerance test, blood glucose increased from 10.4 to $15.5 \mathrm{mmol} / \mathrm{l}$ (Fig. 1). The serum insulin and $\mathrm{C}$-peptide did not change during the test. Plasma IAPP showed no significant changes. During the oral glucose tolerance test blood glucose increased from 10.2 to $16.7 \mathrm{mmol} / \mathrm{l}$ (Fig.2). Serum insulin and Cpeptide increased at the end of the test, while plasma IAPP remained unchanged. During the glucagon stimulation test the C-peptide increased from 0.51 to $0.68 \mathrm{nmol} / 1$ and the insulin increased from 43 to $75 \mathrm{pmol} / \mathrm{l}$ between 0 and $6 \mathrm{~min}$. The plasma IAPP did not change (data not shown).

During the euglycaemic insulin clamp the desired blood glucose level of $5.3 \mathrm{mmol} / \mathrm{l}$ was reached after $80 \mathrm{~min}$. The clamp was continued for another $70 \mathrm{~min}$. The last 50 min were used for the calculation of glucose disposal, which had reached its steady-state level during that period. The glucose-disposal rate was $6.52 \mathrm{mg} \cdot \mathrm{kg}^{-1} \cdot \mathrm{min}^{-1}$ $\left(8.4 \pm 1.8 \mathrm{mg} \cdot \mathrm{kg}^{-1} \cdot \mathrm{min}^{-1}\right.$, mean $\pm \mathrm{SD}$ for age-matched normotensive control subjects) and the steady-state level of serum insulin was $55 \mathrm{mU} / \mathrm{l}(330 \mathrm{pmol} / \mathrm{l})$ (Fig. 3). This gives an insulin sensitivity index of 11.9 (the amount of glucose metabolised per unit of plasma insulin in $\mathrm{mg}$. $\mathrm{kg}^{-1} \cdot \mathrm{min}^{-1}$ per $\mathrm{mU} / 1$ multiplied by 100 ; reference values $9.8 \pm 3.6$, mean \pm SD for age-matched normotensive control subjects [29]). The C-peptide gradually decreased during the clamp and the plasma IAPP levels showed an oscillating curve.

The in vitro experiments with rat pancreatic islets, cultured for 4 days with a $10 \%$ supplementation of 

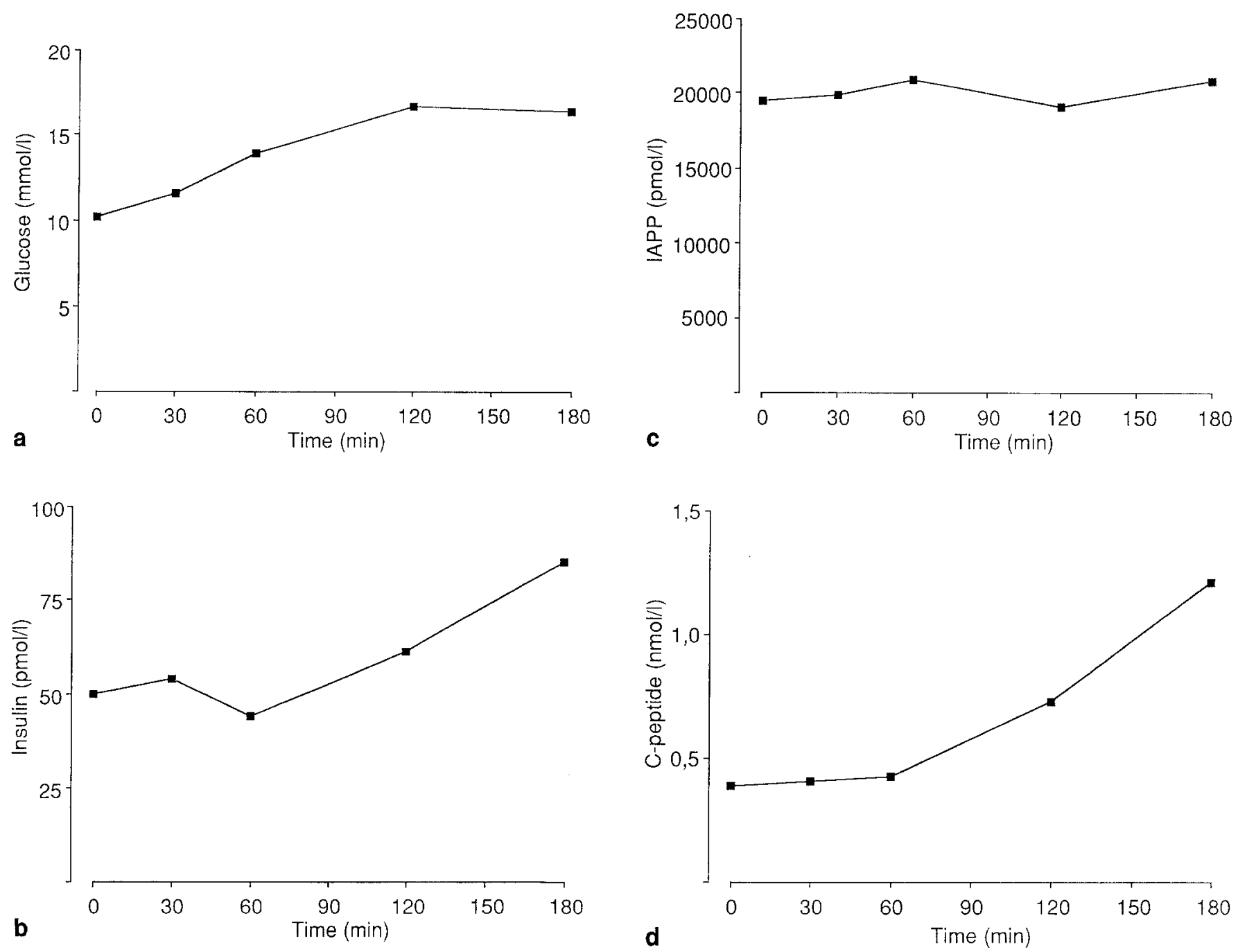

Fig. 2 a-d. Concentrations of blood glucose, serum insulin, serum Cpeptide and plasma islet amyloid polypeptide (IAPP) during an oral glucose tolerance test (75-g glucose)

the patient's serum, showed a significant decrease in the glucose oxidation rates $(30 \%)$ and insulin release stimulated by $16.7 \mathrm{mmol} / \mathrm{l}$ glucose $(27 \%)$ as compared with the islets incubated with the normal human serum (Table 1). The insulin content in the islets and the accumulated insulin in the culture media did not differ between the groups. The number of islet cells was not affected as suggested by the similar DNA contents in all groups.

In another series of experiments, rat pancreatic islets were cultured for 4 days in the presence of $10 \%$ normal human serum supplemented with 0,2 and $200 \mathrm{nmol} / 1$ of synthesized rat IAPP, respectively. However, the glucose-stimulated insulin release at $16.7 \mathrm{mmol} / \mathrm{l}$ glucose did not differ between the groups (control: $109 \pm 14 \mathrm{ng}$ insulin/ $\mu \mathrm{g}$ DNA; $2 \mathrm{pmol} / \mathrm{l}$ IAPP: $101 \pm 5 \mathrm{ng}$ insulin $/ \mu \mathrm{g}$

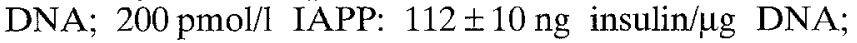
$n=9$ in all groups).

\section{Discussion}

The almost 400 -fold increase in the blood level of an IAPP-like peptide found in our patient is interesting in the context of the current debate regarding a putative diabetogenic action of IAPP $[32,33]$. The lack of any islet cell antibodies within 2 years of diabetes duration makes a diagnosis of Type 1 (insulin-dependent) diabetes unlikely. The patient was non-obese and had no family history of Type 2 diabetes. It is also unlikely that the pancreatic beta cells should have been damaged by the streptozotocin treatment that was given as an anti-tumour treatment, since diabetes is rarely reported at the doses of streptozotocin administered to the patient [34]. Furthermore, the diabetes developed before this therapy was started, clearly demonstrated by the two pathological glucose tolerance tests performed before the streptozotocin treatment. Therefore, a direct diabetogenic effect of the immensely elevated IAPP must be considered.

It has been reported in experimental animals that concentrations of IAPP in the range of $10^{-8}$ to $10^{-5} \mathrm{~mol} / \mathrm{l} \mathrm{can}$ induce decreased glucose-stimulated insulin secretion [12-17], although some experiments have failed to show any inhibitory effects at IAPP concentrations in the range 


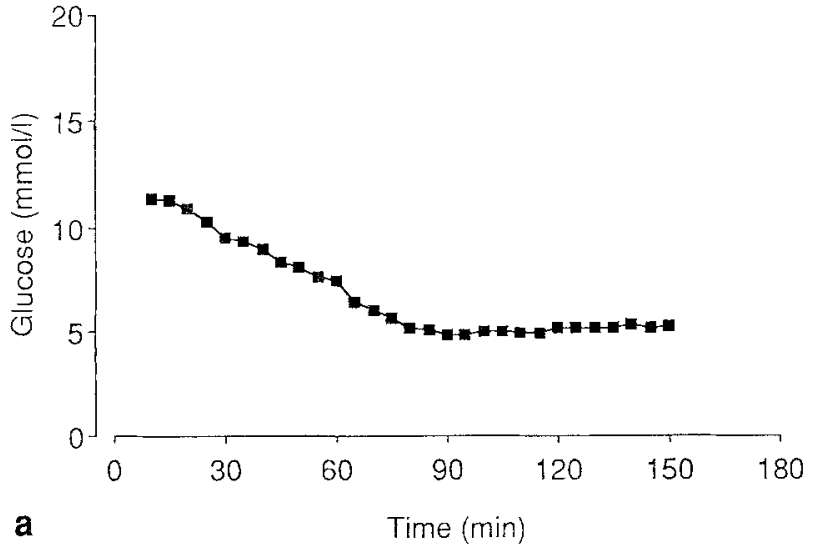

a

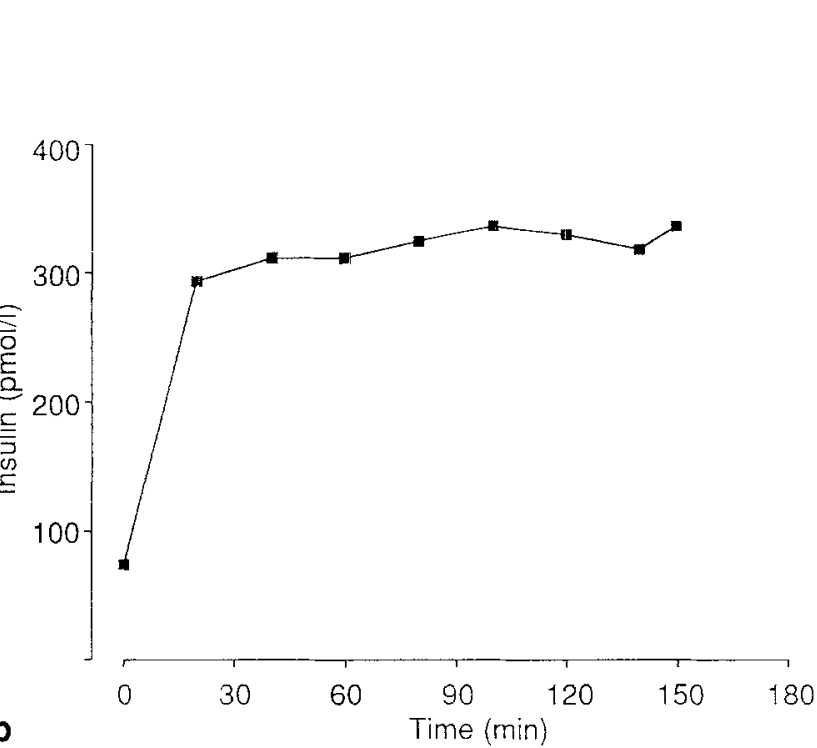

Fig. 3a-d. Concentrations of plasma glucose, serum insulin, serum C-peptide and plasma islet amyloid polypeptide (IAPP) during an euglycaemic insulin clamp

of $10^{-6}$ to $10^{-7} \mathrm{~mol} / \mathrm{l}[18-21]$. These different results may to some extent be explained by the use of different sources of IAPP since different biological activity has been reported with various IAPP preparations [35]. It is also known that human IAPP tends to form amyloid, which also can reduce the true (active) concentrations of IAPP in the incubation media. However, in a recent study where IAPP was infused intravenously into human volunteers at concentrations at about $2200 \mathrm{pmol} / \mathrm{l}$, decreased insulin release during an intravenous glucose tolerance test was shown [36] while similar results could not be repeated at $1200 \mathrm{pmol} / \mathrm{l}$. For comparison, our patient had about 10 times higher circulating concentrations of IAPP than the 2200 which resulted in decreased insulin release in the healthy volunteers.

Both intravenous and oral glucose tolerance tests suggest that there is an inhibition of the early insulin response to glucose stimulation, however a late response was detected during the oral test. In response to glucagon stimu-
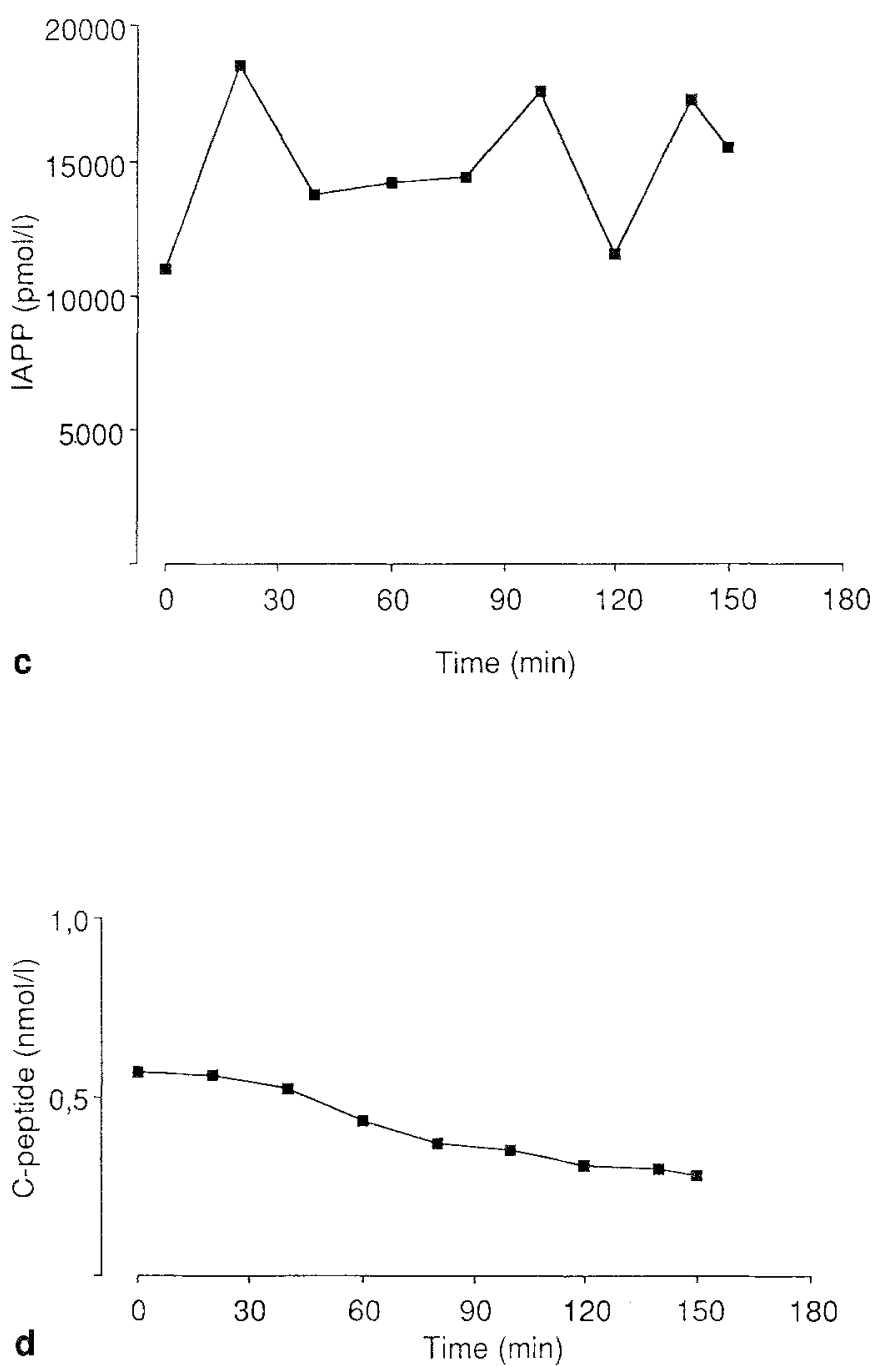

lation, a moderate increase of both insulin and C-peptide was seen at $6 \mathrm{~min}$. These findings indicate that the early phase of the glucose-stimulated insulin release was preferentially inhibited. These findings are also similar to what is seen in early Type 1 diabetes, where a differential sensitivity of the beta cells to different secretagogues has been shown [37].

The in vitro experiments with rat islets confirmed a direct inhibition of the insulin secretion and glucose metabolism in the rat pancreatic islets cultured in the presence of serum from the patient, since both the glucose oxidation and the glucose-stimulated insulin secretion was significantly decreased. These effects were recorded despite dilution of the patient's serum 10-fold in the culture medium. No reduction of the glucose-stimulated insulin release was recorded after culture in the presence of human serum supplemented with rat IAPP in concentrations of 2 and $200 \mathrm{nmol} / \mathrm{l}$, respectively. Thus, it cannot be excluded that the circulating IAPP-like molecules in this patient have different biological effects than "normal" IAPP or that the serum from the patient contains some unknown component that affects the insulin release.

Previously, euglycaemic clamp studies and glucose tolerance tests during intravenous infusions of IAPP have been performed in experimental animals. During infusion 
of IAPP at a rate of $50 \mathrm{pmol} \cdot \mathrm{kg}^{-1} \cdot \mathrm{min}^{-1}$, resulting in IAPP concentrations at about 50 times the basal level, no effect was seen on the insulin-stimulated glucose disposal rates in dogs [38]. In two other studies, where infusion rates were about 100 times higher $\left(5 \mathrm{nmol} \cdot \mathrm{kg}^{-1} \cdot \mathrm{min}^{-1}\right)$, significant reductions of the insulin-stimulated glucose disposal rates were recorded in both dogs and rats $[39,40]$. The insulin-mediated glucose disposal rate found in the present study was within the normal range for healthy men of the same age, although the circulating levels of IAPP were about 400 times above the upper reference value. Thus, if IAPP contributes to the precipitation of Type 2 diabetes by its effects on insulin resistance, an inhibition of the insulin-stimulated glucose disposal rate would have been anticipated by the elevated IAPP levels in this patient.

During all tests, plasma IAPP was oscillating at high levels, about 15000 to $25000 \mathrm{pmol} / \mathrm{l}$. These fluctuations were probably due to the spontaneous release of the IAPP-like molecule from the tumours and apparently the tumours did not respond to the different secretory stimuli. It is thus possible that this molecule may exert biological effects that are different than the "normal" IAPP-molecule since it probably is a pro-peptide with six additional amino acids in the C-terminal. This may be of some significance since the biological activity of the IAPP-molecule is dependent on an amidation of the C-terminal. Nevertheless, this molecule can apparently exert biological effects. The high circulating levels of IAPP in this patient may be in the range of the local concentrations reached in the intra-islet milieu, thus mimicking the autocrine/paracrine-like effects possibly exerted by IAPP [41].

In conclusion, metabolic investigations were performed on a patient with a malignant endocrine pancreatic tumour, producing markedly elevated circulating levels of an IAPP-like molecule, and a concomitant development of diabetes during tumour progression. The results suggest that if IAPP has a diabetogenic effect it is more likely to be exerted at the level of insulin secretion than at the level of peripheral insulin sensitivity.

Acknowledgements. This work was supported by grants from the Swedish Cancer Foundation, the Swedish Diabetes Association, the Swedish Medical Research Council (12P-10739; 12X-109;12X-6817; 12X-8273), the Nordic Insulin Foundation, the Hoechst Diabetes Foundation, the Torsten and Ragnar Söderberg Foundation, Erik, Karin and Gösta Selanders Foundation and the Ludwig Institute for Cancer Research. We also thank Professor H. Lithell (Department of Geriatrics, University Hospital, Uppsala, Sweden) for providing the technical facilities for the euglycaemic clamp.

\section{References}

1. Westermark P, Wernstedt C, Wilander E, Sletten K (1986) A novel peptide in the calcitonin gene related family as an amyloid fibril protein in the endocrine pancreas. Biochem Biophys Res Commun 140: 827-831

2. Westermark P, Wernstedt C, Wilander E, Hayden DW, O'Brien TD, Johnson KH (1987) Amyloid fibrils in human insulinoma and islets of Langerhans of the diabetic cat are derived from a neuropeptide-like protein also present in normal islet cells. Proc Natl Acad Sci USA 84: 3881-3885
3. Cooper GJS, Willis AC, Clark A, Turner RC, Sim RB, Reid KBM (1987) Purification and characterization of a peptide from amyloid-rich pancreas of type 2 diabetic patients. Proc Natl Acad Sci USA 84: 8628-8632

4. Clark A, Edwards CA, Ostle LR et al. (1989) Localisation of islet amyloid peptide in lipofuscin bodies and secretory granules of human B-cells and in islets of type-2 diabetic subjects. Cell Tissue Res 257: 179-185

5. Toshimori H, Narita R, Nakazato M et al. (1990) Islet amyloid polypeptide (IAPP) in the gastrointestinal tract and pancreas of man and rat. Cell Tissue Res 262: 401-406

6. Nakazato M, Asai J, Kangawa K, Matsukura S, Matsuo H (1989) Establishment of radioimmunoassay for human islet amyloid polypeptide and its tissue content and plasma concentration. Biochem Biophys Res Commun 164: 394-399

7. Ferrier GJ, Pierson AM, Jones PM, Bloom SR, Girgis SI, Legon S (1989) Expression of the rat amylin (IAPP/DAP) gene. J Mol Endocrinol 3: R1-R4

8. Lukinius A, Wilander E, Westermark GT, Engström U, Westermark P (1989) Co-localization of islet amyloid polypeptide and insulin in the $B$ cell secretory granules of the human pancreatic islets. Diabetologia 32: 240-244

9. Fehmann HC, Weber V, Goke R, Goke B, Arnold R (1990) Cosecretion of amylin and insulin from isolated rat pancreas. FEBS Lett 262: 279-281

10. Hartter E, Svoboda T, Ludvik B et al. (1991) Basal and stimulated plasma levels of pancreatic amylin indicate its co-secretion with insulin in humans. Diabetologia 34: 52-54

11. Cooper GJ, Leighton B, Dimitriadis GD et al. (1988) Amylin found in amyloid deposits in human type 2 diabetes mellitus may be a hormone that regulates glycogen metabolism in skeletal muscle. Proc Natl Acad Sci USA 85: 7763-7766

12. Ar'Rajab A, Ahren B (1991) Effects of amidated rat islet amyloid polypeptide on glucose-stimulated insulin secretion in vivo and in vitro in rats. Eur J Pharmacol 192: 443-445

13. Ghatei MA, Datta HK, Zaidi Met al. (1990) Amylin and amylinamide lack an acute effect on blood glucose and insulin. $J$ Endocrinol 124: R9-R11

14. Kogire M, Ishizuka J, Thompson JC, Greeley GH Jr (1991) Inhibitory action of islet amyloid polypeptide and calcitonin generelated peptide on release of insulin from the isolated perfused rat pancreas. Pancreas 6:459-463

15. Nagamatsu S, Carroll RJ, Grodsky GM, Steiner DF (1990) Lack of islet amyloid polypeptide regulation of insulin biosynthesis or secretion in normal rat islets. Diabetes 39: 871-874

16. Ohsawa H, Kanatsuka A, Yamaguchi T, Makino H, Yoshida S (1989) Islet amyloid polypeptide inhibits glucose-stimulated insulin secretion from isolated rat pancreatic islets. Biochem Biophys Res Commun 160: 961-967

17. Silvestre RA, Peiro E, Degano P, Miralles P, Marco J (1990) Inhibitory effect of rat amylin on the insulin responses to glucose and arginine in the perfused rat pancreas. Regul Pept 31: 23-32

18. Broderick CL, Brooke GS, DiMarchi RD, Gold G (1991) Human and rat amylin have no effects on insulin secretion in isolated rat pancreatic islets. Biochem Biophys Res Commun 177: 932-938

19. O'Brien TD, Westermark P, Johnson KH (1990) Islet amyloid polypeptide (IAPP) does not inhibit glucose-stimulated insulin secretion from isolated perfused rat pancreas. Biochem Biophys Res Commun 170: 1223-1228

20. Pettersson M, Ahren B (1990) Failure of islet amyloid polypeptide to inhibit basal and glucose-stimulated insulin secretion in model experiments in mice and rats. Acta Physiol Scand 138: 389-394

21. Tedstone AE, Nezzer T, Hughes SJ, Clark A, Matthews DR (1990) The effect of islet amyloid polypeptide (amylin) and calcitonin gene-related peptide on glucose removal in the anesthetized rat and on insulin secretion from rat pancreatic islets in vitro. Biosci Rep 10: 339-346

22. Koopmans SJ, Van Mansfeld ADM, Jansz HS et al. (1991) Amylin-induced in vivo insulin resistance in conscious rats: the 
liver is more sensitive to amylin than peripheral tissues. Diabetologia 34: $218-224$

23. Deems RO, Deacon RW, Young DA (1991) Amylin activates glycogen phosphorylase and inactivates glycogen synthase via a cAMP-independent mechanism. Biochem Biophys Res Commun 174: 716-720

24. Morishita T, Yamaguchi A, Fujita T, Chiba T (1990) Activation of adenylate cyclase by islet amyloid polypeptide with $\mathrm{COOH}-$ terminal amide via calcitonin gene-related peptide receptors and rat liver plasma membranes. Diabetes 39: 875-877

25. Datta HK, Zaidi M, Wimalawansa SJ et al. (1989) In vivo and in vitro effects of amylin and amylin-amide on calcium metabolism in the rat and rabbit. Biochem Biophys Res Commun 162:876-881

26. Brain SD, Wimalawansa S, MacIntyre I, Williams TJ (1990) The demonstration of vasodilator activity of pancreatic amylin amide in the rabbit. Am J Pathol 136: 487-490

27. Stridsberg M, Wilander E, Oberg K, Lundqvist G, Eriksson B (1992) Islet amyloid polypeptide-producing pancreatic islet cell tumor: a clinical and biochemical characterization. Scand J Gastroenterol 27: 381-387

28. DeFronzo RA, Tobin JD, Andres R (1979) Glucose clamp technique: a method for quantifying insulin secretion and resistance. Am J Physiol 237: 214-233

29. Pollare T, Lithell H, Berne C (1990) Insulin resistance is a characteristic feature of primary hypertension independent of obesity. Metabolism 39: 167-174

30. Landin-Olsson M, Sundkvist G, Lernmark $\AA$ (1987) Prolonged incubation in the two-colour immunofluorescence test increases the prevalence and titres of islet cell antibodies in type 1 (insulindependent) diabetes mellitus. Diabetologia 30: 327-332

31. Sandler S, Andersson A, Hellerström C (1987) Inhibitory effects of interleukin 1 on insulin secretion, insulin biosynthesis, and oxidative metabolism of isolated rat pancreatic islets. Endocrinology 121: 1424-1431

32. Steiner DF, Ohagi S, Nagamatsu S, Bell GI, Nishi M (1991) Is islet amyloid polypeptide a significant factor in pathogenesis or pathophysiology of diabetes? Diabetes 40:305-309

33. Johnson KH, O'Brien TD, Westermark P' (1991) Newly identified pancreatic protein islet amyloid polypeptide. What is its relationship to diabetes? Diabetes $40: 310-314$
34. Öberg K, Norheim I, Lundqvist G, Wide L (1987) Cytotoxic treatment in patients with malignant carcinoid tumors. Response to streptozocin - alone or in combination with 5-FU. Acta Oncol 26: 429-432

35. Cody WL, Giordani AB, Werness S et al. (1991) Analysis of rat amylin amide from commercial sources: identification of a mercury complex. Bioorg Med Chem Lett 1: 415-420

36. Bretherton-Watt D, Gilbey SG, Ghatei MA, Beacham J, Macrae AD, Bloom SR (1992) Very high concentrations of islet amyloid polypeptide are necessary to alter the insulin response to intravenous glucose in man. J Clin Endocrinol Metab 74: 10321035

37. Ganda OP, Srikanta S, Brink SJ et al. (1984) Differential sensitivity to beta-cell secretagogues in "early", type 1 diabetes mellitus. Diabetes 33: 516-521

38. Kassir AA, Upadhyay AK, Lim TJ, Moossa AR, Olefsky JM (1991) Lack of effect of islet amyloid polypeptide in causing insulin resistance in conscious dogs during euglycemic clamp studies. Diabetes 40: 998-1004

39. Sowa R, Sanke T, Hirayama J et al. (1990) Islet amyloid polypeptide amide causes peripheral insulin resistance in vivo in dogs. Diabetologia 33: 118-120

40. Molina JM, Cooper GJS, Leighton B, Olefsky JM (1990) Induction of insulin resistance in vivo by amylin and calcitonin gene-related peptide. Diabetes 39: 260-265

41. Bretherton-Watt D, Bloom SR (1991) Islet amyloid polypeptide. The cause of type-2 diabetes? Trends Endocrinol Metab 2: 203206

Received: 11 February 1993

and in revised form: 21 April 1993

Dr. M.Stridsberg

Department of Clinical Chemistry

University Hospital

S-751 85 Uppsala

Sweden 